Discussion Paper No. 15-090

Mobile and More Productive?

Firm-Level Evidence on the Productivity

Effects of Mobile Internet Use

Irene Bertschek and Thomas Niebel

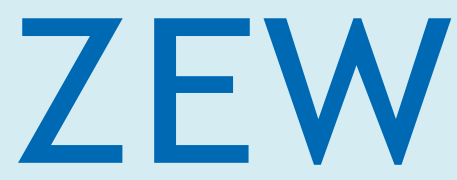

Zentrum für Europäische Wirtschaftsforschung $\mathrm{GmbH}$

Centre for European

Economic Research 
Discussion Paper No. 15-090

\title{
Mobile and More Productive? Firm-Level Evidence on the Productivity Effects of Mobile Internet Use
}

\author{
Irene Bertschek and Thomas Niebel
}

Download this ZEW Discussion Paper from our ftp server:

http://ftp.zew.de/pub/zew-docs/dp/dp15090.pdf

Die Discussion Papers dienen einer möglichst schnellen Verbreitung von neueren Forschungsarbeiten des ZEW. Die Beiträge liegen in alleiniger Verantwortung der Autoren und stellen nicht notwendigerweise die Meinung des ZEW dar.

Discussion Papers are intended to make results of ZEW research promptly available to other economists in order to encourage discussion and suggestions for revisions. The authors are solely responsible for the contents which do not necessarily represent the opinion of the ZEW. 


\title{
Mobile and More Productive? Firm-Level Evidence on the Productivity Effects of Mobile Internet Use
}

\author{
Irene Bertschek* Thomas Niebel ${ }^{\dagger}$
}

This Version December 2015

First Version December 2013

\begin{abstract}
Mobile internet access allows for flexibility with respect to working time and working place. We analyse whether employees' use of mobile internet access improves firms' labour productivity. Our data set contains 2143 German firms and refers to the year 2014, when high-speed mobile internet was still at a relatively early stage of diffusion within firms. The econometric analysis shows that firms' labour productivity significantly increases with the share of employees with mobile internet access. Our instrumental variables approach reveals that mobile internet use does cause higher labour productivity.
\end{abstract}

Keywords: Mobile Internet, Labour Productivity, Firm-Level Data.

JEL Classification Numbers: D22, L20, O33.

\footnotetext{
${ }^{*}$ Corresponding author: ZEW Mannheim and University of Mannheim, email: bertschek@zew.de, Centre for European Economic Research (ZEW), ICT Research Department, P.O. Box 103443, 68034 Mannheim, Germany.

${ }^{\dagger}$ ZEW Mannheim, niebel@zew.de. For further information on projects of the authors see www.zew.de/staff_ ibe and www.zew.de/staff_tni as well as the ZEW annual report on www.zew.de/en. We thank Wolfgang Briglauer, Konrad Stahl and the participants at the EARIE conference (Munich) for helpful comments and James Binfield for research assistance. Financial support by the state of Baden-Württemberg is gratefully acknowledged.
} 


\section{Introduction}

Computers and the internet are well-established working tools. They have changed workplaces significantly, contributed to improving labour productivity and changed the demand for employee skills and qualifications. The technological prerequisites for mobile internet, which is diffusing rapidly through the economy, are advances in high-speed wireless connections and mobile devices such as laptops, tablets and smartphones. McKinsey Global Institute (2013) considers mobile internet as one of twelve disruptive technologies with a very high potential economic impact. OECD (2012, p.22) motivates the transformation from the information economy to the internet economy and points out that "Wireless internet connections are the key source of recent internet growth, increasing rapidly since 2001 and overtaking fixed broadband subscriptions in 2009." In Germany, the number of regular high speed mobile internet users increased from 13.6 million in 2008 to 52.6 million in 2014. During the same period, mobile data volume increased even more rapidly, from 11.5 to 394.8 Petabytes (see Figure A.1).

While the role of information and communication technologies (ICT) in determining labour productivity is well studied, ${ }^{1}$ there is, to the best of our knowledge, no empirical work on the firm-level productivity effects of mobile internet so far. Why would we expect productivity effects from mobile internet? One important result from the empirical analysis of ICT is that reduced communication costs support the decentralisation of organisation, such as the reduction of hierarchy levels and the implementation of autonomous working teams (see for example Bresnahan et al., 2002). Mobile internet access can further improve information flows and communication and reduce involved costs. Employees are now able to access their firms' data and documents anywhere, at any time. This supports decentralisation in terms of organisation and time. By contrast, coordination costs might increase if physical meetings become more difficult to arrange since everybody wants to be flexible. Moreover, monitoring might become more difficult if employees work geographically dispersed. Thus, the net contribution of mobile internet is a priori not evident.

In our analysis, we take a firm-level perspective in order to analyse the role that employees' mobile internet access plays for firms' labour productivity. Based on a sample of 2143 firms from the German manufacturing and services industry, we estimate classical production functions. Mobile internet use as an input factor is measured by the percentage share of employees with mobile internet access in each firm. We control for ICT use at the workplace other than mobile internet access by including measures of the use of computers and access to fixed line internet. Since the estimates of the effect of mobile internet access might be prone to reverse causality, i.e. more productive firms have more resources to invest in new technologies, we apply an instrumental variables approach. We instrument employees' mobile internet use within firms by the average mobile internet use of 51 industries and by the number of years the interviewee owns a smartphone.

\footnotetext{
${ }^{1}$ See for instance the literature reviews by Draca et al. (2007), Van Reenen et al. (2010), Bertschek (2012), and Cardona et al. (2013).
} 
Our initial econometric analysis shows that a one percentage point higher share of employees with mobile internet access is associated with a 0.2 percent higher labour productivity. When controlling for potential endogeneity bias by instrumental variables estimation, we still find a significant effect of mobile internet use on firm productivity. Thus, based on our sample of 2143 German firms for the year 2014, we can claim that mobile internet access has a causal impact on firms' labour productivity.

Our paper contributes to the literature in various respects: (i) We provide first microeconometric firm-level evidence on the labour productivity effects of employees' mobile internet use. (ii) We control for computer use and fixed line internet access as further types of ICT use at the workplace. (iii) By applying an instrumental variables approach we take account of potential reverse causality between labour productivity and mobile internet use.

\section{Related Literature}

To the best of our knowledge, there is no microeconometric study referring to the relationship between mobile internet use by employees and firms' labour productivity. There is, however, a quite extensive literature on the economic impact of mobile phones for small and micro enterprises in developing and emerging countries (e.g. Jensen 2007, Muto and Yamano 2009, Aker and Mbiti 2010, Tadesse and Bahiigwa 2015 and Paunov and Rollo 2016). In general, this literature suggests that the use of mobile phones improves market outcomes. Furthermore, there exist various studies in information systems research and psychology about the implications of communication technologies and especially mobile internet use (i.e. constant connectivity) for individual employees. Middleton and Cukier (2006) provide a qualitative analysis on the mobile email usage patterns of individual employees. Their participants report positive aspects like allowing them to be efficient as well as negative aspects like the infringement on work-life boundaries. Diaz et al. (2012) conclude that the use of communication technologies is associated with increased work satisfaction, but could also create work-life conflicts. The studies by Mazmanian et al. (2013), Mazmanian (2013) and Dery et al. (2014) provide further descriptive evidence on the implications of constant connectivity and always on work practices for employees.

Apart from that, there is a broad literature on productivity effects of ICT in general as well as for fixed-line broadband internet. According to the survey by Cardona et al. (2013), the estimated production elasticity of ICT ranges on average between 0.05 and 0.06 and has increased over the period of observation. Some studies analyse the contribution of the internet to productivity. At the macro level, Koutroumpis (2009) and Czernich et al. (2011) show that broadband internet has a positive and statistically significant impact on both productivity and growth in OECD countries. ${ }^{2}$ Using a novel data set at the meso-level, Hagsten (forthcoming) finds a positive and significant relationship between labour productivity and the share of broadband-enabled employees in firms

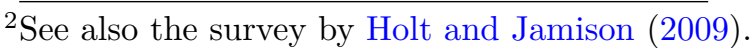


with the strength of relationships varying considerably across countries and industries. At the micro level, the evidence is rather mixed. Based on a cross section of firms from New Zealand collected in 2006, Grimes et al. (2012) find that firms using broadband internet have a 7 to 10 percent higher labour productivity. By contrast, for the early phase of broadband diffusion in Germany, 2000 to 2002, Bertschek et al. (2013) find positive and significant effects of broadband on firms' innovation activity but not on their labour productivity. Comparable insignificant results are found by De Stefano et al. (2014) for British firms and by Haller and Lyons (2015) for Irish firms. Akerman et al. (2015) again find, based on Norwegian data that a 10 percentage point increase in broadband availability raises output by 0.4 percent. A positive relationship between innovation and employees' broadband access is also found by Polder et al. (2010) using Dutch firm-level data. As Colombo et al. (2013) demonstrate for the case of small Italian firms, it is not necessarily the connection to the internet that matters but what firms do with the internet that might make them more productive.

A few macroeconometric studies analyse the role of mobile phones or mobile telecommunication services that are not necessarily related to the internet and that do not specifically refer to employees' mobile internet access. Based on a cross-country data set Vu (2011) studies the impact of ICT in terms of personal computers, mobile phones and internet users on economic growth. He finds positive and significant effects for all three types of technology. The analysis by Ward and Zheng (forthcoming) reveals positive effects of mobile telephone services on growth in China. This effect is larger for the first period from 1991 to 2000 than for the second from 2001 to 2010, thus the effect declines with the economic development of Chinese provinces.

\section{Estimation Strategy}

In order to analyse the impact of mobile internet access on labour productivity we apply a production function framework as a standard approach to empirically analyse the relationship between productivity and technology. A firm's production process is modelled by a Cobb-Douglas production function with various input factors:

$$
Y_{i}=A_{i} L_{i}^{\alpha_{L}} K_{i}^{\alpha_{K}} e^{\beta_{M O B} M O B_{i}} e^{\beta_{W W W} W W W_{i}} e^{\beta_{P C} P C_{i}} e^{\gamma_{X} X_{i}}
$$

Output $Y_{i}$ is a function of labour $L_{i}$, capital $K_{i}$ and total factor productivity $A_{i}$. The production function is augmented by the share of workers predominantly using computers $\left(P C_{i}\right)$, having internet access $\left(W W W_{i}\right)$, and having mobile internet access $\left(M O B_{i}\right)$. Mobile internet access is measured as the share of employees that the company has equipped with mobile devices like smartphones, tablets and notebooks providing internet access via cellular networks. A vector of various control variables $X_{i}$ captures a firm's share of highly qualified employees, export activity, share of young employees, regional location (East or West Germany), remote email access, and its 
sector affiliation (17 industries).

Our main interest is in the relationship between labour productivity defined as sales per employee $\left(Y_{i} / L_{i}\right)$ and mobile internet $M O B_{i}$. Taking logs of the production function results in:

$$
\begin{array}{r}
\ln \left(\frac{Y_{i}}{L_{i}}\right)=\ln A_{i}+\left(\alpha_{L}-1\right) \ln L_{i}+\alpha_{K} \ln K_{i}+\beta_{M O B} M O B_{i}+ \\
\beta_{W W W} W W W_{i}+\beta_{P C} P C_{i}+\gamma_{\mathbf{X}} \mathbf{X}_{\mathbf{i}}+u_{i}
\end{array}
$$

where $\alpha_{L}, \alpha_{K}$ represent the output elasticities of labour and capital, respectively, and $\beta_{(\bullet)}$ refer to the output elasticities with respect to employees' ICT use.

Our main hypothesis is that the coefficient of mobile internet use $\beta_{M O B}$ is larger than zero. Mobile internet access is expected to further decrease communication costs and thereby allows employees to autonomously decide on their most efficient working place and working time. By contrast, the alternative hypothesis is that reduced communication costs and improved decentralisation are outweighed by increased monitoring and coordination costs rendering the effect of mobile internet use zero. Strictly speaking, our measure of mobile internet is a measure of mobile internet access. It measures the share of employees with mobile internet devices and not their actual use of these devices. It seems to be plausible, however, that employees who are equipped with mobile devices by their employers will also use these devices to access the internet. Therefore, we apply the terms mobile internet access and mobile internet use as synonyms.

Productivity and ICT use might be simultaneously determined since firms choose their inputs depending on the output they plan to produce and vice versa. We argue that one can distinguish between the different types of ICT use with respect to their potential endogeneity. Computers (mainframes) had started to diffuse in the 1960s, particularly in the financial sector. Personal computers diffused to firms mainly in the $80 \mathrm{~s}$ and $90 \mathrm{~s}$, whereas the internet diffused to firms in the 90s and early 2000s. As diffusion rates show (from 33.8 percent in 2000 to 55.6 percent in 2007 and 58.4 percent in 2014 - see Figure A.2), the fraction of workplaces equipped with computers and internet access has been quite stable during the last few years. The firm's production process determines the appropriate degree of ICT use within the firm. A certain percentage of employees might be equipped with computers whereas others might have jobs or tasks that are not directly related to the use of ICT. Thus, it is reasonable to assume that in the year 2014, the diffusion of computers and internet access has reached a point of saturation and further diffusion will only take place at a slow rate. Therefore, we conclude that computer use and internet access are quasi-fixed input factors and rule out reverse causality for these two variables. In 2014, mobile internet in firms, by contrast, was still at an early stage of diffusion. Only 26 percent of employees in our sample are equipped with mobile devices being able to connect to the internet. We assume that the use of mobile internet is restricted to employees that have used computers and the internet 
before, and that the share of employees using computers or the internet is not affected by mobile internet access. What mobile internet adds to the use of computers and the internet is that it enables users to become more mobile and independent with respect to their working place and working time.

The empirical analysis consists of two steps. In the first step, we estimate various model specifications by simple OLS. In the second step, we apply an instrumental variables approach to take account of potential simultaneity between labour productivity and mobile internet use. In the first stage estimation, two variables are used as instruments for mobile internet access: the average mobile internet use at the level of 51 industries and the number of years the interviewee owns a smartphone.

The number of years the respondent uses a (private) smartphone use is in our view a valid instrument. Electronic mobile devices such as smartphones or tablets as well as applications such as social media started their diffusion process among individuals before diffusing to firms. As the interviewee is usually from the firm's senior management or the IT department, he or she decides or is at least involved in the firms' decision on the investment in mobile internet devices. Thus, the number of years the respondent uses a smartphone might be a good predictor for the extent the firm is using mobile internet devices. However, the entire firm's labour productivity will not depend on the number of years a single person working in this firm owns a smartphone.

The average mobile internet use measured at the level of 51 industries also appears to be a valid instrument. The average share of mobile internet use measured at the level of industries is a good predictor for the share of employees having mobile internet access within the firm since it reflects the stage of diffusion of mobile internet use by employees within firms across industries. By contrast, it does not directly explain a single firm's labour productivity.

In the estimations, we control for factors such as firm size and the share of young employees. Larger firms and those with a higher share of employees younger than 30 years old might have a higher probability of using mobile devices and applications. At the same time, these variables might be positively or negatively related to labour productivity. Moreover, we include a dummy variable measuring whether or not employees have remote access to their email accounts. This is a kind of application that employees could access with their mobile devices via mobile internet but also via fixed-line internet. All estimations include dummies for 17 industries (these 17 industries refer to a higher aggregation level than the 51 industries the instrumental variable refers to) and controls for export activity and location (East/West Germany).

\section{Data and Measures}

Our analysis is based on the ZEW ICT survey which is a survey of manufacturing and businessrelated services firms that are located in Germany and have at least five employees. ${ }^{3}$ In each of the

${ }_{3}^{3}$ The data are available at the ZEW Research Data Centre - http://kooperationen.zew.de/en/zew-fdz. 
six waves, collected in 2000, 2002, 2004, 2007, 2010 and 2014, about 4400 firms were interviewed about their characteristics and particularly about their ICT usage. The data were collected via computer-aided telephone interviews (CATI) based on a sample stratified with respect to industry and firm size. The survey is designed as a panel but not all firms responded in all waves. For our analysis, we use the 2014 wave. This wave is the second one containing information about mobile internet use. Taking account of item non-response and implausible values, we end up with a sample of 2143 firms. ${ }^{4}$ As suggested by Table A.3, the observations not included in the estimation sample are missing at random.

The central variables of our analysis are labour productivity as the performance measure and the use of computers, as well as access to the internet and to mobile internet, as measures of ICT use at the workplace. Labour productivity is measured as sales per employee. The firms were asked about the percentage of employees working with computers most of the time and the percentage of employees having access to the internet. To capture mobile internet use, firms were asked about the percentage of employees with mobile internet access. More precisely, the three corresponding questions asked in the survey are:

- What is the percentage of employees working predominantly with computers?

- What is the percentage of employees who have access to the internet?

- What is the percentage of employees that your company has equipped with mobile devices like smartphones, tablets and notebooks that provide internet access via cellular networks?

The first question reflects the usage of computers by the employees, whereas the other two measure the access to the internet. The percentage of employees working with computers as a measure of ICT intensity is also used in other studies as for instance Bloom et al. (2012). Table 4.1 shows descriptive statistics of the sample. On average, a firm has 125 employees and 25.6 million euro in sales. 48 percent of the firms are engaged in export activities and the average share of highly qualified employees is 21 percent. On average, 48 percent of the employees work predominantly with computers, 60 percent have internet access and 27 percent have mobile internet access via UMTS or LTE. The figures for mobile internet use demonstrate that in 2014, mobile internet in firms was still at a relatively early stage of diffusion, although its diffusion has almost doubled compared to 2010 (see Figure A.3 in the Appendix). Differentiating between firms with and without mobile internet use reveals that firms that equip their employees with mobile internet devices (86 percent of the firms in the sample) have a higher labour productivity, are considerably larger, have higher sales and invest more. Furthermore, they are more ICT intensive and have a

\footnotetext{
${ }^{4}$ We dropped firms with sales per employee less than 10,000 Euro (4 observations) and more than 1 million Euro (43), with total investment larger than turnover (9), with less than 5 employees (163), with more than 5000 employees (19) and ICT investment larger than total investment (1 observation). Since investment is taken in logs, zero investment is replaced by the 10th percentile of investment per employee observed in the corresponding industry multiplied by the number of employees. Missing investment information is replaced by the 50th percentile of the corresponding industry.
} 
higher share of highly qualified employees (see Table A.2 in the Appendix). For the distribution of firms across industries, see Table A.3.

The first instrumental variable used in the IV estimations refers to the (log) number of years the interviewee owns a smartphones. The average number of years, the interviewee owns a smartphone is 6.03 years, with the highest share in the media services industry (see Figure A.4 in the Appendix). Our second instrumental variable is the average share of mobile internet use in 51 industries, with a mean of 25 percent.

Table 4.1: Summary Statistics: Estimation Sample

\begin{tabular}{lrrrrrr}
\hline & $\mathrm{N}$ & Mean & Median & SD & Min & Max \\
\hline Sales in Mill. Euro & 2143 & 25.6 & 3.50 & 115.9 & 0.10 & 2500 \\
Employees & 2143 & 125.0 & 31 & 360.9 & 5 & 5000 \\
Labour Productivity (Sales per Emp.) & 2143 & 0.16 & 0.11 & 0.14 & 0.010 & 1 \\
Investment in Mill. Euro & 2143 & 1.26 & 0.15 & 5.72 & 0.00050 & 130 \\
\% of Emp. Predom. Using PC & 2143 & 0.48 & 0.38 & 0.35 & 0 & 1 \\
\% of Emp. Using Internet & 2143 & 0.60 & 0.60 & 0.37 & 0 & 1 \\
\% of Emp. Using Mob. Internet & 2143 & 0.27 & 0.16 & 0.29 & 0 & 1 \\
Smartphone since t Years & 2143 & 6.03 & 5 & 3.65 & 1 & 21 \\
Remote Email Access & 2143 & 0.74 & 1 & 0.44 & 0 & 1 \\
\% Highly Qualified Employees & 2143 & 0.21 & 0.10 & 0.25 & 0 & 1 \\
\% of Employees < Age 30 & 2143 & 0.24 & 0.21 & 0.17 & 0 & 1 \\
East Germany Dummy & 2143 & 0.23 & 0 & 0.42 & 0 & 1 \\
Export Dummy & 2143 & 0.48 & 0 & 0.50 & 0 & 1 \\
Labour Productivity (in logs) & 2143 & -2.16 & -2.17 & 0.76 & -4.61 & 0 \\
Employees (in logs) & 2143 & 3.63 & 3.43 & 1.39 & 1.61 & 8.52 \\
Investment (in logs) & 2143 & -1.78 & -1.90 & 1.92 & -7.60 & 4.87 \\
Smartphone since t Years (logs) & 2143 & 1.61 & 1.61 & 0.65 & 0 & 3.04 \\
Av. \% Mob. Inter. & 2143 & 0.25 & 0.22 & 0.14 & 0.10 & 0.63 \\
\hline
\end{tabular}

\section{Results}

Table 5.1 presents results from simple OLS estimations. All three ICT inputs — share of employees working with computers, having access to the internet and being equipped with mobile internet access - have positive and highly significant coefficients, thus revealing a positive correlation with labour productivity. The coefficients for the share of employees with mobile internet access and the share of employees working with computers remain highly significant even when all three ICT variables are included in the estimation (specification 6). A one percentage point higher share of employees with mobile internet access is associated with an approximately 0.2 percent higher labour productivity.

In the next step, we perform an instrumental variables estimation. ${ }^{5}$ We instrument the firms' shares of mobile internet users with the average mobile internet use in 51 industries and the number

\footnotetext{
${ }^{5}$ The analysis was carried out in Stata using the IVREG2 command provided by Baum et al. (2010).
} 
of years the interviewee owns a smartphone. First stage results are shown in Table A.1. The first column uses just the number of years the interviewee owns a smartphone as an instrument and the second column only takes into account the average share of employees with mobile internet access at the industry level. Column (3), our preferred specification, uses the combination of both instruments.

Table 5.1: Dependent Variable: Log Labour Productivity - OLS Regression

\begin{tabular}{lcccccc}
\hline & $(1)$ & $(2)$ & $(3)$ & $(4)$ & $(5)$ & $(6)$ \\
\hline \% of Emp. Using Mob. Internet & & $0.226^{* * *}$ & & & $0.180^{* * *}$ & $0.165^{* * *}$ \\
& & $(0.057)$ & & & $(0.055)$ & $(0.057)$ \\
\% of Emp. Predom. Using PC & & & $0.526^{* * *}$ & & $0.507^{* * *}$ & $0.460^{* * *}$ \\
& & & $(0.069)$ & & $(0.069)$ & $(0.077)$ \\
\% of Emp. Using Internet & & & & $0.310^{* * *}$ & & 0.079 \\
& & & & $(0.053)$ & & $(0.060)$ \\
Employees (in logs) & $-0.082^{* * *}$ & $-0.085^{* * *}$ & $-0.082^{* * *}$ & $-0.081^{* * *}$ & $-0.070^{* * *}$ & $-0.068^{* * *}$ \\
& $(0.016)$ & $(0.016)$ & $(0.016)$ & $(0.016)$ & $(0.016)$ & $(0.017)$ \\
Investment (in logs) & $0.163^{* * *}$ & $0.143^{* * *}$ & $0.141^{* * *}$ & $0.142^{* * *}$ & $0.137^{* * *}$ & $0.137^{* * *}$ \\
Constant & $(0.012)$ & $(0.012)$ & $(0.012)$ & $(0.012)$ & $(0.012)$ & $(0.012)$ \\
& $-1.677^{* * *}$ & $-1.823^{* * *}$ & $-1.893^{* * *}$ & $-1.884^{* * *}$ & $-1.949^{* * *}$ & $-1.966^{* * *}$ \\
Industry Dummies & $(0.084)$ & $(0.086)$ & $(0.086)$ & $(0.088)$ & $(0.088)$ & $(0.089)$ \\
Additional Controls & Yes & Yes & Yes & Yes & Yes & Yes \\
\hline Observations & No & Yes & Yes & Yes & Yes & Yes \\
Adjusted $R^{2}$ & 2143 & 2143 & 2143 & 2143 & 2143 & 2143 \\
\hline
\end{tabular}

Robust standard errors in parentheses, ${ }^{*} \mathrm{p}<0.10,{ }^{* *} \mathrm{p}<0.05,{ }^{* * *} \mathrm{p}<0.01$.

Additional Controls: Exports, East Germany, Remote Email, \% Highly Qualified and \% of Employees < Age 30 .

The Angrist-Pischke F-test, which in our case of a single endogenous regressor equals the standard F-test for weak identification, has rather large values between 21 and 60 (see Table 5.2). The Kleibergen-Paap LM-test is a heteroscedasticity-robust test for underidentification. In all our specifications, the null hypothesis is rejected, meaning that the model is identified. Furthermore, the Hansen J-test does not reject the null hypothesis of no correlation between residuals and instruments in the specifications (3). These results suggest that our instruments are relevant for explaining a firm's share of employees equipped with mobile internet access.

The estimated coefficient of mobile internet use of the second stage estimations of specifications (2) to (3) are still significant, implying that mobile internet use has a causal positive effect on labour productivity. ${ }^{6}$ The coefficient of our preferred specification (3) of Table 5.2 is, however,

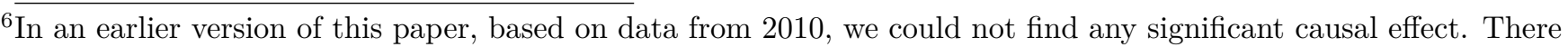
are three different explanations for the diverging results: (1) weak instruments in the old version, (2) network effects in firms, as there are now much more employees equipped with mobile internet devices and (3) the fact that 
noticeably larger than the OLS results in Table 5.1.

Table 5.2: Dependent Variable: Log Labour Productivity - 2SLS Regression - Second Stage

\begin{tabular}{|c|c|c|c|}
\hline & (1) & $(2)$ & (3) \\
\hline \% of Emp. Using Mob. Internet & $\begin{array}{c}0.748 \\
(0.555)\end{array}$ & $\begin{array}{c}0.929^{* * *} \\
(0.336)\end{array}$ & $\begin{array}{c}0.891^{* * *} \\
(0.292)\end{array}$ \\
\hline$\%$ of Emp. Predom. Using PC & $\begin{array}{c}0.472^{* * *} \\
(0.081)\end{array}$ & $\begin{array}{c}0.476^{* * *} \\
(0.082)\end{array}$ & $\begin{array}{c}0.475^{* * *} \\
(0.082)\end{array}$ \\
\hline$\%$ of Emp. Using Internet & $\begin{array}{l}-0.040 \\
(0.132)\end{array}$ & $\begin{array}{l}-0.077 \\
(0.094)\end{array}$ & $\begin{array}{l}-0.069 \\
(0.088)\end{array}$ \\
\hline Employees (in logs) & $\begin{array}{l}-0.035 \\
(0.035)\end{array}$ & $\begin{array}{l}-0.025 \\
(0.026)\end{array}$ & $\begin{array}{l}-0.027 \\
(0.024)\end{array}$ \\
\hline Investment (in logs) & $\begin{array}{c}0.127^{* * *} \\
(0.015)\end{array}$ & $\begin{array}{c}0.124^{* * *} \\
(0.014)\end{array}$ & $\begin{array}{c}0.125^{* * *} \\
(0.013)\end{array}$ \\
\hline Constant & $\begin{array}{c}-2.114^{* * *} \\
(0.166)\end{array}$ & $\begin{array}{c}-2.160^{* * *} \\
(0.128)\end{array}$ & $\begin{array}{c}-2.150^{* * *} \\
(0.120)\end{array}$ \\
\hline Industry Dummies & Yes & Yes & Yes \\
\hline Additional Controls & Yes & Yes & Yes \\
\hline Instrument & Years Smartphone & 51 Industry Averages & Both \\
\hline Adjusted $R^{2}$ & 0.323 & 0.299 & 0.305 \\
\hline Kleibergen-Paap LM P-value & 0.000 & 0.000 & 0.000 \\
\hline Angrist-Pischke F-test & 20.745 & 59.302 & 37.844 \\
\hline Endogeneity Test P-value & 0.277 & 0.015 & 0.008 \\
\hline Hansen J-test P-value & & & 0.780 \\
\hline Observations & 2143 & 2143 & 2143 \\
\hline
\end{tabular}

Robust standard errors in parentheses, ${ }^{*} \mathrm{p}<0.10,{ }^{* *} \mathrm{p}<0.05,{ }^{* * *} \mathrm{p}<0.01$.

Additional Controls: Exports, East Germany, Remote Email, \% Highly Qualified and \% of Employees $<$ Age 30.

the capabilities of the mobile devices, networks (UMTS vs. LTE) and software increased dramatically between 2010 and 2014. 


\section{Conclusions and Future Research}

According to our empirical results, mobile internet use is positively and significantly related with firms' labour productivity. Our instrumental variables estimates suggest that this relationship is indeed causal. The positive aspects of mobile internet, like the improved information flows and the support for a more decentralized organisation of the firm, seem to outweigh the increased difficulty of monitoring the employees.

There are various avenues for future research. First, in order to learn more about how mobile internet can improve labour productivity, it is important to know which resources employees have access to when working remotely. Do they have access only to their email accounts or also to data bases and enterprise software? Second, we also know from previous studies that investment in ICT should be accompanied by complementary investment in organisation and human capital in order to be fully utilised (see for example Bresnahan et al., 2002 or Bloom et al., 2012).

The recent paper by Bloom et al. (2015) finds positive impacts from introducing working from home on employees' performance. Godart et al. (2014) find positive evidence for the impact of introducing trust-based working on plants' probability to realise product innovations. Thus, further analysis should take account of workplace models that are flexible with respect to working time and working place and that are supported by mobile devices, such as home office, co-working, working while traveling, etc.

Finally, improving work-life balance and creating the possibility to combine work and family i.e. working from home arrangements) are important assets for firms aiming to acquire and retain highly qualified employees, in particular in times of demographic change. At the same time, there are controversial discussions about the health risks of worker flexibility related to being always and everywhere online. This could, although not testable with our cross-sectional data set, diminish the positive productivity effect of mobile internet in the long run. For evaluating the potential of mobile internet, we need new concepts for measuring mobility not only with respect to the technical dimension but also with respect to working place and working time. Such a multidimensional concept, however, renders a causal analysis non-trivial, thus posing several challenges for future research. 


\section{References}

Aker, J. C. and Mbiti, I. M. (2010), 'Mobile Phones and Economic Development in Africa', The Journal of Economic Perspectives 24(3), 207-232.

Akerman, A., Gaarder, I. and Mogstad, M. (2015), 'The Skill Complementarity of Broadband Internet', Quarterly Journal of Economics 130(4), 1781-1824.

Baum, C. F., Schaffer, M. E. and Stillman, S. (2010), 'IVREG2: Stata Module for Extended Instrumental Variables/2SLS, GMM and AC/HAC, LIML and k-Class Regression', Statistical Software Components, Boston College Department of Economics. Available at http://ideas . repec.org/c/boc/bocode/s425401.html.

Bertschek, I. (2012), ICT, Internet and Worker Productivity, in S. N. Durlauf and L. E. Blume, eds, 'The New Palgrave Dictionary of Economics', Palgrave Macmillan. Online Edition.

Bertschek, I., Cerquera, D. and Klein, G. J. (2013), 'More Bits-More Bucks? Measuring the Impact of Broadband Internet on Firm Performance', Information Economics and Policy 25(3), 190203.

Bloom, N., Liang, J., Roberts, J. and Ying, Z. (2015), 'Does Working from Home Work? Evidence from a Chinese Experiment', Quarterly Journal of Economics 130(1), 165-218.

Bloom, N., Sadun, R. and Van Reenen, J. (2012), 'Americans Do IT Better: US Multinationals and the Productivity Miracle', American Economic Review 102(1), 167-201.

Bresnahan, T. F., Brynjolfsson, E. and Hitt, L. M. (2002), 'Information Technology, Workplace Organization, and the Demand for Skilled Labor: Firm-Level Evidence', The Quarterly Journal of Economics 117(1), 339-376.

Bundesnetzagentur (2012), 'Annual Report 2011'. Available at http: //www . bundesnetzagentur . de/SharedDocs/Downloads/EN/BNetzA/PressSection/ReportsPublications/2012/ AnnualReport2011pdf .pdf?__blob=publicationFile.

Bundesnetzagentur (2015), 'Tätigkeitsbericht Telekommunikation 2014/2015'. Available at http://www.bundesnetzagentur.de/cln_1422/DE/Allgemeines/Presse/Mediathek/ Berichte/berichte-node.html.

Cardona, M., Kretschmer, T. and Strobel, T. (2013), 'ICT and Productivity: Conclusions from the Empirical Literature', Information Economics and Policy 25(3), 109-125.

Colombo, M. G., Croce, A. and Grilli, L. (2013), 'ICT Services and Small Businesses' Productivity Gains: An Analysis of the Adoption of Broadband Internet Technology', Information Economics and Policy 25(3), 171-189. 
Czernich, N., Falck, O., Kretschmer, T. and Woessmann, L. (2011), 'Broadband Infrastructure and Economic Growth', The Economic Journal 121(552), 505-532.

De Stefano, T., Kneller, R. and Timmis, J. (2014), The (Fuzzy) Digital Divide: The Effect of Broadband Internet Use on UK Firm Performance, Discussion Papers 14/06, University of Nottingham, School of Economics.

Dery, K., Kolb, D. and MacCormick, J. (2014), 'Working with Connective Flow: How Smartphone Use is Evolving in Practice', European Journal of Information Systems 23(5), 558-570.

Diaz, I., Chiaburu, D. S., Zimmerman, R. D. and Boswell, W. R. (2012), 'Communication Technology: Pros and Cons of Constant Connection to Work', Journal of Vocational Behavior 80(2), 500-508.

Draca, M., Sadun, R. and Van Reenen, J. (2007), Productivity and ICT: A Review of the Evidence, in R. Mansell, ed., 'The Oxford Handbook of Information and Communication Technologies', Oxford University Press, pp. 100-147.

Godart, O. N., Görg, H. and Hanley, A. (2014), Trust-Based Work-Time and Product Improvements: Evidence from Firm Level Data, Kiel Working Papers 1913, Kiel Institute for the World Economy.

Grimes, A., Ren, C. and Stevens, P. (2012), 'The Need for Speed: Impacts of Internet Connectivity on Firm Productivity', Journal of Productivity Analysis 37(2), 187-201.

Hagsten, E. (forthcoming), 'Broadband Connected Employees and Labour Productivity: A Comparative Analysis of 14 European Countries Based on Distributed Microdata Access', Economics of Innovation and New Technology pp. 1-17. Available at http://dx.doi.org/10. $1080 / 10438599.2015 .1105547$.

Haller, S. A. and Lyons, S. (2015), 'Broadband Adoption and Firm Productivity: Evidence from Irish Manufacturing Firms', Telecommunications Policy 39(1), 1-13.

Holt, L. and Jamison, M. (2009), 'Broadband and Contributions to Economic Growth: Lessons from the US Experience', Telecommunications Policy 33(10), 575-581.

Jensen, R. (2007), 'The Digital Provide: Information (Technology), Market Performance, and Welfare in the South Indian Fisheries Sector', The Quarterly Journal of Economics 122(3), 879924.

Koutroumpis, P. (2009), 'The Economic Impact of Broadband on Growth: A Simultaneous Approach', Telecommunications Policy 33(9), 471-485.

Mazmanian, M. (2013), 'Avoiding the Trap of Constant Connectivity: When Congruent Frames Allow for Heterogeneous Practices', Academy of Management Journal 56(5), 1225-1250. 
Mazmanian, M., Orlikowski, W. J. and Yates, J. (2013), 'The Autonomy Paradox: The Implications of Mobile Email Devices for Knowledge Professionals', Organization Science 24(5), 13371357.

McKinsey Global Institute (2013), 'Disruptive Technologies: Advances that will Transform Life, Business, and the Global Economy'. Available at http://www.mckinsey.com/insights/ business_technology/disruptive_technologies.

Middleton, C. A. and Cukier, W. (2006), 'Is Mobile Email Functional or Dysfunctional? Two Perspectives on Mobile Email Usage', European Journal of Information Systems 15(3), 252260.

Muto, M. and Yamano, T. (2009), 'The Impact of Mobile Phone Coverage Expansion on Market Participation: Panel Data Evidence from Uganda', World Development 37(12), 1887-1896.

OECD (2012), OECD Internet Economy Outlook 2012, OECD Publishing.

Paunov, C. and Rollo, V. (2016), 'Has the Internet Fostered Inclusive Innovation in the Developing World?', World Development 78, 587-609.

Polder, M., Leeuwen, G. v., Mohnen, P. and Raymond, W. (2010), Product, Process and Organizational Innovation: Drivers, Complementarity and Productivity Effects, UNU-MERIT Working Paper Series 2010-035, United Nations University, Maastricht Economic and Social Research and Training Centre on Innovation and Technology.

Tadesse, G. and Bahiigwa, G. (2015), 'Mobile Phones and Farmers' Marketing Decisions in Ethiopia', World Development 68, 296-307.

Van Reenen, J., Bloom, N., Draca, M., Kretschmer, T. and Sadun, R. (2010), The Economic Impact of ICT, Centre for Economic Performance, London School of Economics. Available at http: //ec.europa.eu/information_society/newsroom/cf/dae/document.cfm?doc_id=669.

Vu, K. M. (2011), 'ICT as a Source of Economics Growth in the Information Age: Empirical Evidence from the 1996-2005 Period', Telecommunications Policy 35(4), 357-372.

Ward, M. R. and Zheng, S. (forthcoming), 'Mobile Telecommunications Service and Economic Growth: Evidence from China', Telecommunications Policy pp. 1-13. Available at http://dx. doi.org/10.1016/j.telpol.2015.06.005. 


\section{A Appendix}

\section{A.1 Additional Graphs}

Figure A.1: Mobile Data Volumes and 3G/4G Users in Germany 2005-2014

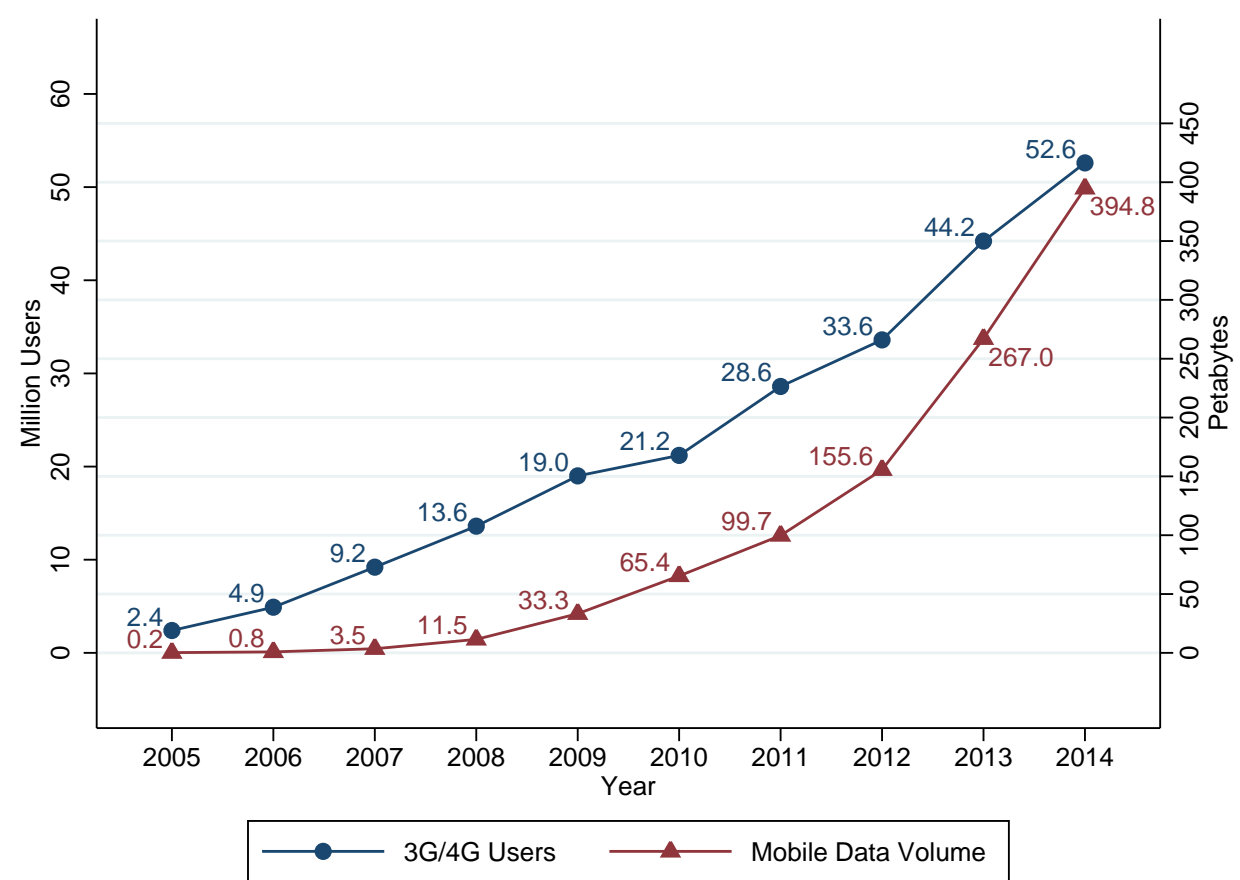

Source: Bundesnetzagentur (2012) page 83 and Bundesnetzagentur (2015) page 40.

Figure A.2: Share of Employees Using (Mobile) Internet/Predominately Work with Computers: Full Sample

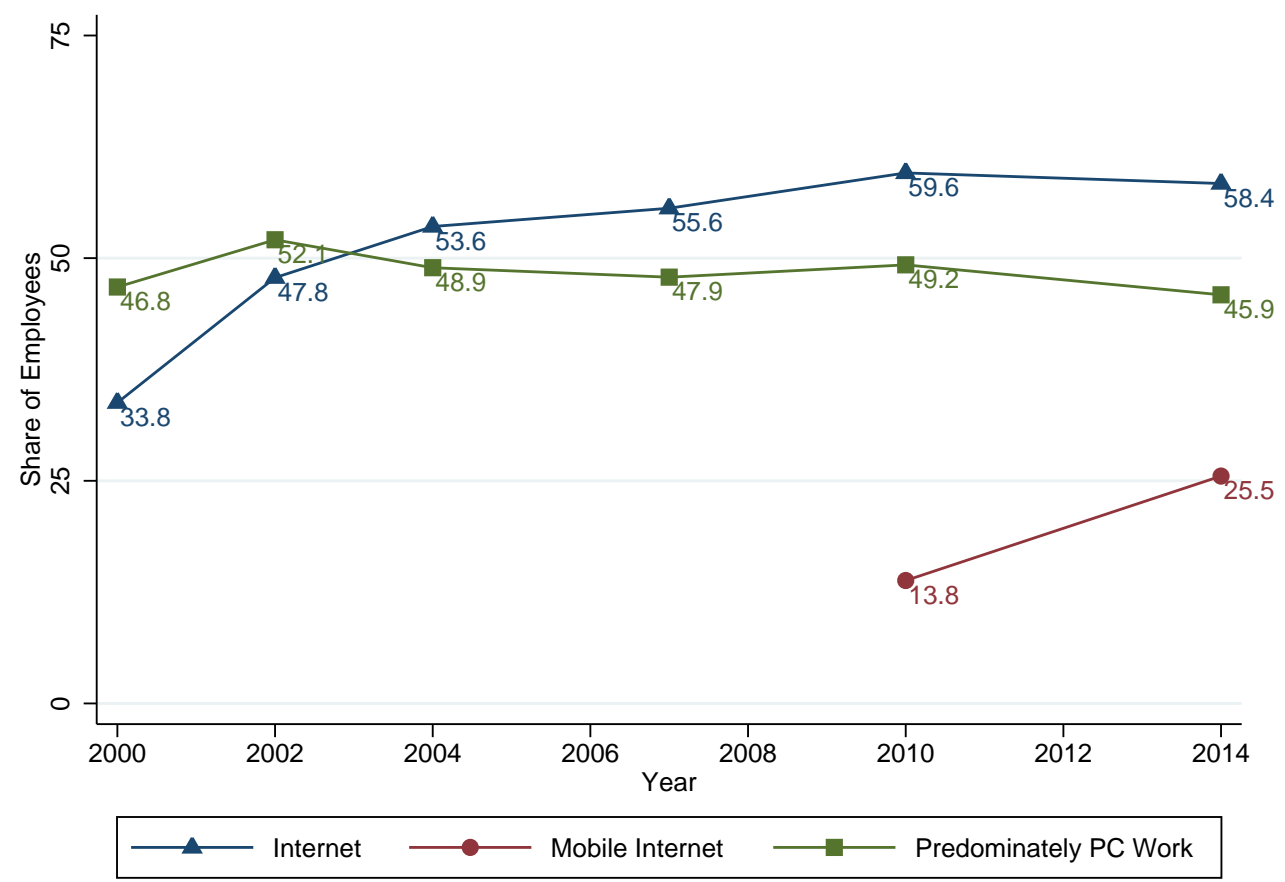

Source: ZEW ICT surveys 2000, 2002, 2004, 2007, 2010 and 2014. 
Figure A.3: Share of Employees Using Mobile Internet: Estimation Sample

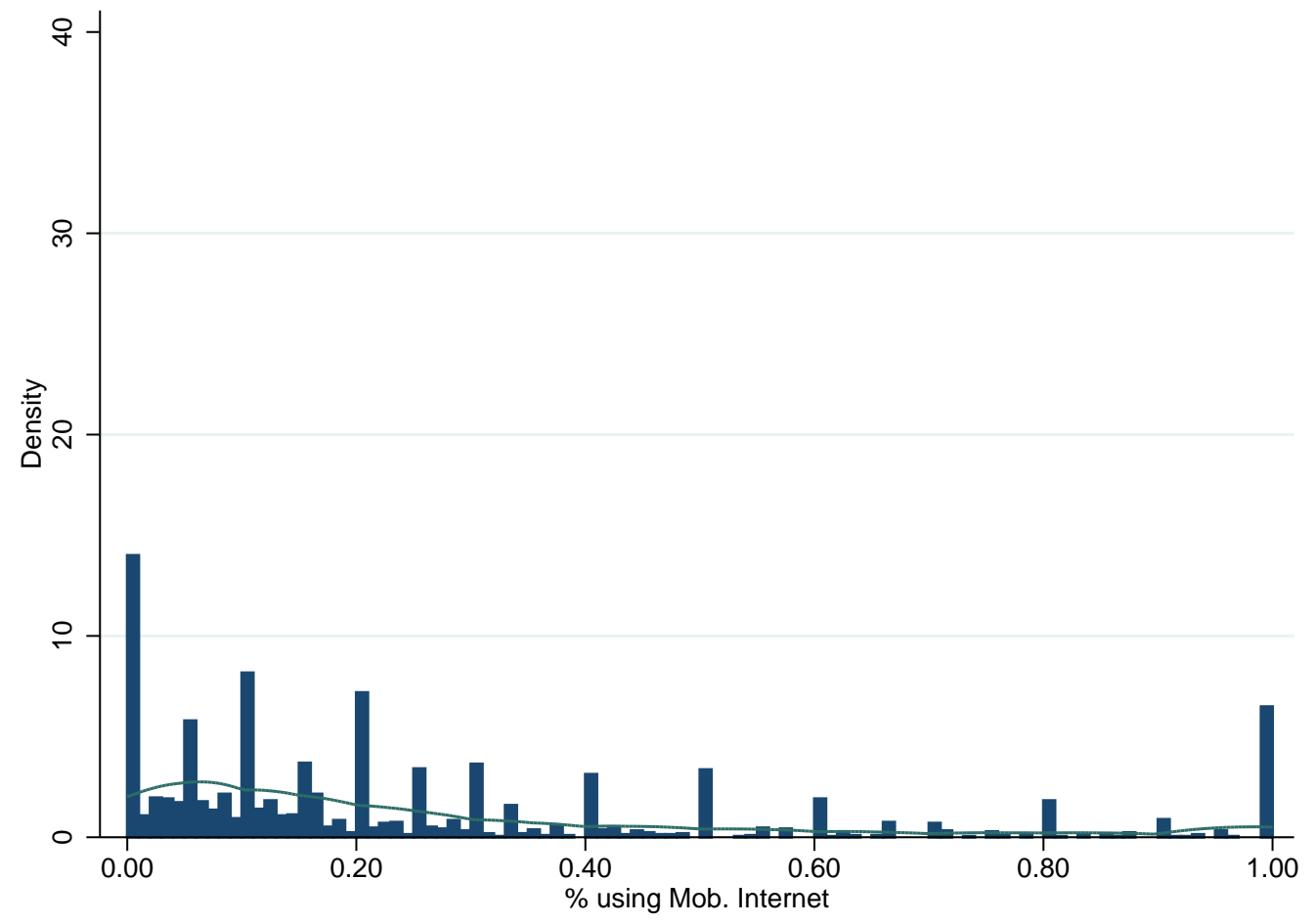

Source: ZEW ICT survey 2014.

Figure A.4: Industry Means of Mobile Internet Use: Estimation Sample

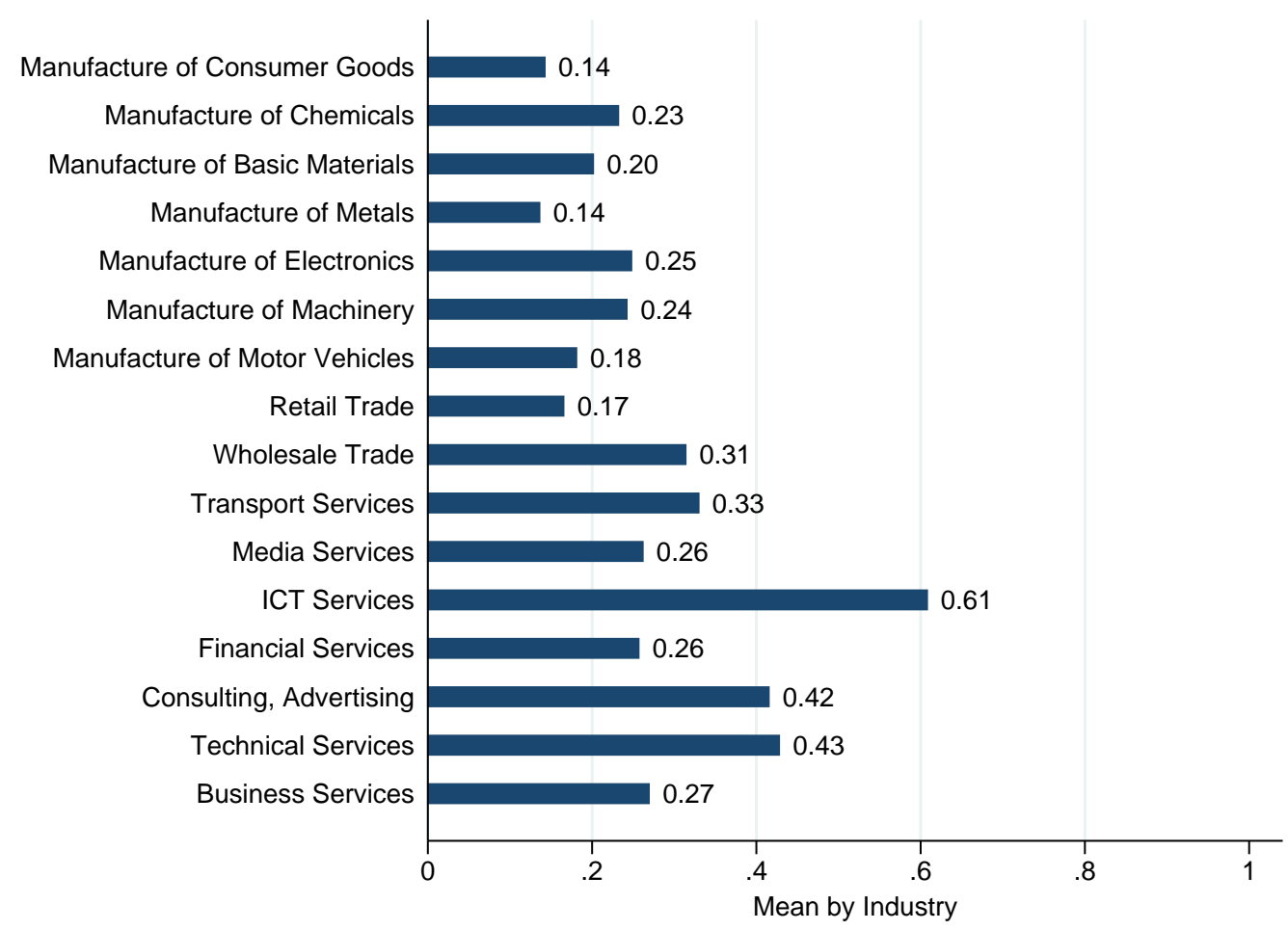

Source: ZEW ICT survey 2014. 
Figure A.5: Industry Means of the Number of Years the Interviewee owns a Smartphone: Estimation Sample

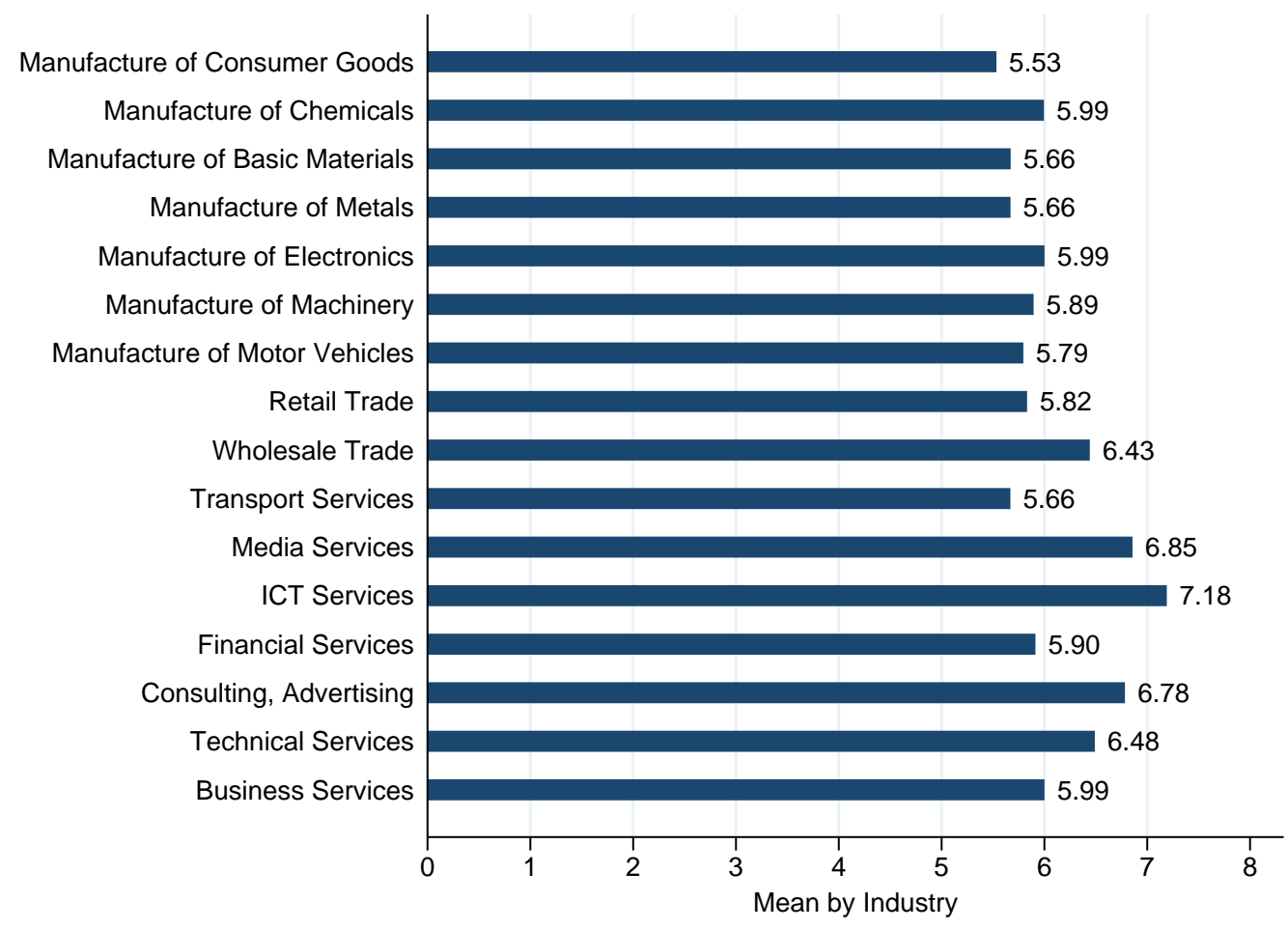

Source: ZEW ICT survey 2014. 


\section{A.2 Additional Tables}

Table A.1: Dependent Variable: Percentage of Employees using Mobile Internet - 2SLS Regression First Stage of Table 5.2

\begin{tabular}{lccc}
\hline & $(1)$ & $(2)$ & $(3)$ \\
\hline Smartphone since t Years (logs) & $0.038^{* * *}$ & & $0.035^{* * *}$ \\
& $(0.008)$ & $0.008)$ \\
Av. \% Mob. Inter. & & $0.741^{* * *}$ & $0.728^{* * *}$ \\
& & $(0.096)$ & $(0.096)$ \\
\% of Emp. Predom. Using PC & -0.022 & -0.032 & -0.032 \\
& $(0.032)$ & $(0.031)$ & $(0.031)$ \\
\% of Emp. Using Internet & $0.201^{* * *}$ & $0.210^{* * *}$ & $0.206^{* * *}$ \\
& $(0.026)$ & $(0.026)$ & $(0.025)$ \\
Employees (in logs) & $-0.057^{* * *}$ & $-0.048^{* * *}$ & $-0.049^{* * *}$ \\
& $(0.007)$ & $(0.006)$ & $(0.006)$ \\
Investment (in logs) & $0.015^{* * *}$ & $0.014^{* * *}$ & $0.012^{* * *}$ \\
& $(0.005)$ & $(0.004)$ & $(0.004)$ \\
Constant & $0.200^{* * *}$ & $0.130^{* * *}$ & $0.082^{* *}$ \\
Industry Dummies & $(0.035)$ & $(0.038)$ & $(0.039)$ \\
Additional Controls & Yes & Yes & Yes \\
\hline Observations & Yes & Yes & Yes \\
\hline
\end{tabular}

Robust standard errors in parentheses, ${ }^{*} \mathrm{p}<0.10,{ }^{* *} \mathrm{p}<0.05,{ }^{* * *} \mathrm{p}<0.01$. 
Table A.2: Summary Statistics by Mobile Internet Use of Firms: Estimation Sample

\begin{tabular}{|c|c|c|c|c|c|c|}
\hline & \multicolumn{2}{|c|}{ Without Mobile } & \multicolumn{2}{|c|}{ With Mobile } & \multicolumn{2}{|c|}{ Total } \\
\hline & $\mathrm{N}$ & Mean & $\mathrm{N}$ & Mean & $\mathrm{N}$ & Mean \\
\hline Sales in Mill. Euro & 299 & 3.29 & 1844 & 29.26 & 2143 & 25.63 \\
\hline Employees & 299 & 30.17 & 1844 & 140.32 & 2143 & 124.95 \\
\hline Labour Productivity (Sales per Emp.) & 299 & 0.12 & 1844 & 0.16 & 2143 & 0.16 \\
\hline Investment in Mill. Euro & 299 & 0.22 & 1844 & 1.43 & 2143 & 1.26 \\
\hline$\%$ of Emp. Predom. Using PC & 299 & 0.34 & 1844 & 0.50 & 2143 & 0.48 \\
\hline$\%$ of Emp. Using Internet & 299 & 0.44 & 1844 & 0.63 & 2143 & 0.60 \\
\hline$\%$ of Emp. Using Mob. Internet & 299 & 0.00 & 1844 & 0.31 & 2143 & 0.27 \\
\hline Smartphone since t Years & 299 & 5.23 & 1844 & 6.16 & 2143 & 6.03 \\
\hline Remote Email Access & 299 & 0.34 & 1844 & 0.80 & 2143 & 0.74 \\
\hline \% Highly Qualified Employees & 299 & 0.11 & 1844 & 0.22 & 2143 & 0.21 \\
\hline$\%$ of Employees < Age 30 & 299 & 0.25 & 1844 & 0.24 & 2143 & 0.24 \\
\hline East Germany Dummy & 299 & 0.19 & 1844 & 0.23 & 2143 & 0.23 \\
\hline Export Dummy & 299 & 0.36 & 1844 & 0.50 & 2143 & 0.48 \\
\hline Labour Productivity (in logs) & 299 & -2.40 & 1844 & -2.12 & 2143 & -2.16 \\
\hline Employees (in logs) & 299 & 2.89 & 1844 & 3.75 & 2143 & 3.63 \\
\hline Investment (in logs) & 299 & -2.79 & 1844 & -1.61 & 2143 & -1.78 \\
\hline Smartphone since t Years $(\operatorname{logs})$ & 299 & 1.42 & 1844 & 1.64 & 2143 & 1.61 \\
\hline Av. \% Mob. Inter. & 299 & 0.19 & 1844 & 0.26 & 2143 & 0.25 \\
\hline
\end{tabular}


Table A.3: Distribution of Firms across Industries

\begin{tabular}{|c|c|c|c|c|}
\hline & \multicolumn{2}{|c|}{ Estimation Sample } & \multicolumn{2}{|c|}{ Full Sample } \\
\hline & $\mathrm{N}$ & Percentage & $\mathrm{N}$ & Percentage \\
\hline Manufacture of Consumer Goods & 320 & 14.93 & 607 & 15.75 \\
\hline Manufacture of Chemicals & 78 & 3.64 & 140 & 3.63 \\
\hline Manufacture of Basic Materials & 202 & 9.43 & 329 & 8.54 \\
\hline Manufacture of Metals & 151 & 7.05 & 279 & 7.24 \\
\hline Manufacture of Electronics & 144 & 6.72 & 237 & 6.15 \\
\hline Manufacture of Machinery & 124 & 5.79 & 231 & 6.00 \\
\hline Manufacture of Motor Vehicles & 61 & 2.85 & 110 & 2.85 \\
\hline Retail Trade & 119 & 5.55 & 228 & 5.92 \\
\hline Wholesale Trade & 106 & 4.95 & 193 & 5.01 \\
\hline Transport Services & 121 & 5.65 & 217 & 5.63 \\
\hline Media Services & 86 & 4.01 & 164 & 4.26 \\
\hline ICT Services & 137 & 6.39 & 223 & 5.79 \\
\hline Financial Services & 105 & 4.90 & 231 & 6.00 \\
\hline Consulting, Advertising & 138 & 6.44 & 231 & 6.00 \\
\hline Technical Services & 114 & 5.32 & 191 & 4.96 \\
\hline Business Services & 137 & 6.39 & 242 & 6.28 \\
\hline Total & 2143 & 100.00 & 3853 & 100.00 \\
\hline
\end{tabular}

Since some firms have industry affiliation that are not conform with the list of industries in our stratification, the total number of firms in the full sample is lower than the 4400 mentioned in Section 4. Additionally, we dropped the very heterogeneous industry 'Manufacture of Furniture and Other Manufacturing' in our estimation sample and therefore also in the full sample for comparability. 